\title{
"Aguardiente, forever" de HILDEBRANDO PÉREZ GRANDE
}

Hildebrando Pérez Grande nació en Lima, Perú, en 1941. Premio de Poesía Casa de las Américas, 1978, por su libro Aguardiente y otros cantares. Profesor Principal de la Facultad de Letras y Ciencias Humanas de la Universidad Nacional Mayor de San Marcos, Lima. -Actualmente Director de la Escuela de Literatura de San Marcos y Codirector del Taller de Poesía de San Marcos. Director Académico de la revista de Arte y Literatura MARTIN, dedicada a poetas y narradores peruanos contemporáneos. Ha sido director de la revista de poesía PIÉLAGO, codirector de la revista de poesía HIPOCRITA LECTOR, y Sub-Director de la revista de Cultura PUENTE-NIPPI. Sus poemas han sido traducidos al inglés, francés, alemán y portugués.

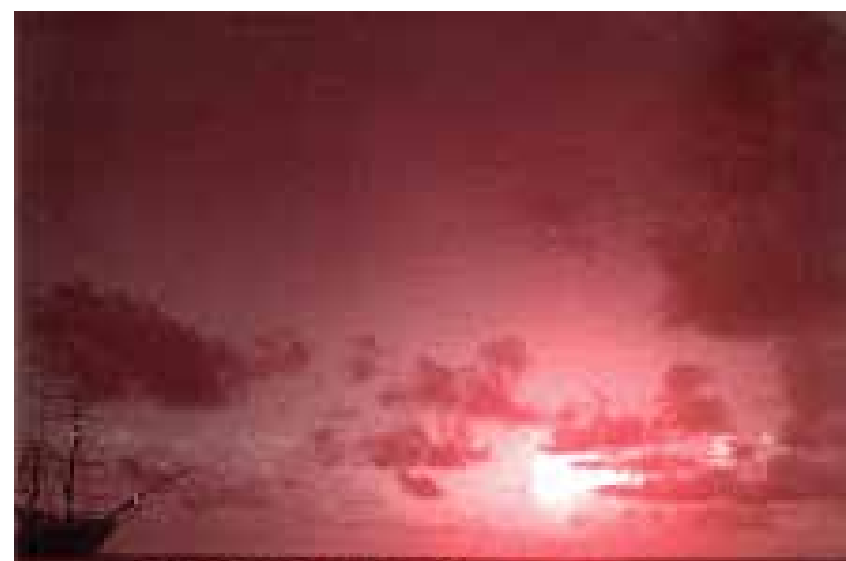

HIIDDEBR MNDO PERE Z GRANDE

\section{Aguardiente, forever}

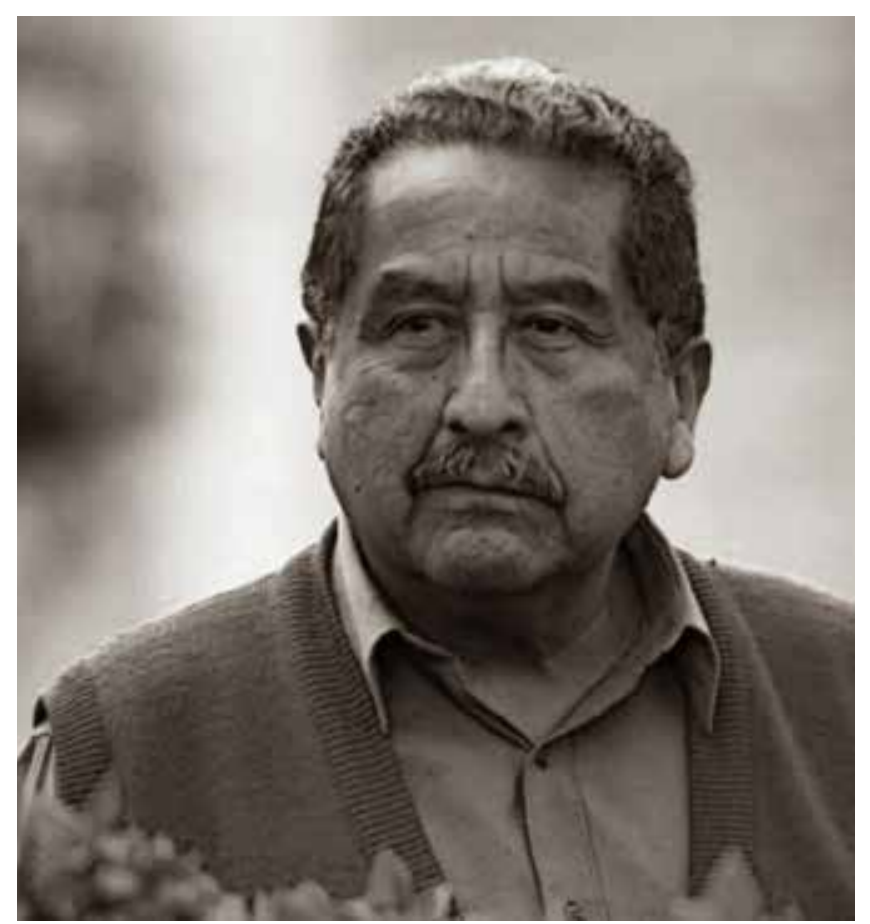

Como lo afirma Raúl Hernández Novás: “...Hallamos en sus versos la conciencia milenaria del hombre de los Andes, tal como ha vivido en las formas poéticas folklóricas: sentido de la tierra y del paisaje, sensibilidad que se expresa a través de delicadas menciones a elementos de la naturaleza, honda solidaridad humana, comunal. Elementos naturales de tradición folklórica como la paloma, el agua, el trigo, las retamas, etc., se integraban en fragmentos que no constituían un calco, sino una recreación de formas populares como el huayno... Hildebrando Pérez Grande ya muestra una voz propia que se nutre, no de una sola tendencia determinada, sino de muchos afluentes... Uno de los valores fundamentales del poemario radica en la capacidad de imaginación. Él no es un conceptista, es un poeta que se expresa por imágenes, y estas se encuentran nítidamente recortadas. Sus imágenes no son símbolos convencionales que poco a poco van apagando su brillo, lexicalizándose; son referencias directas al mundo circundante...". (Hipocampo Editores). 


\section{Poemas de "Aguardiente, forever" de Hildebrando Pérez Grande}

\section{(Selección de Anastasio Lovo)}

\section{Cantar de Hildebrando}

Cuando venga el día, con el

en los pies, con el sol en las manos,

con el sol en la garganta cantaremos.

Wáshington Delgado

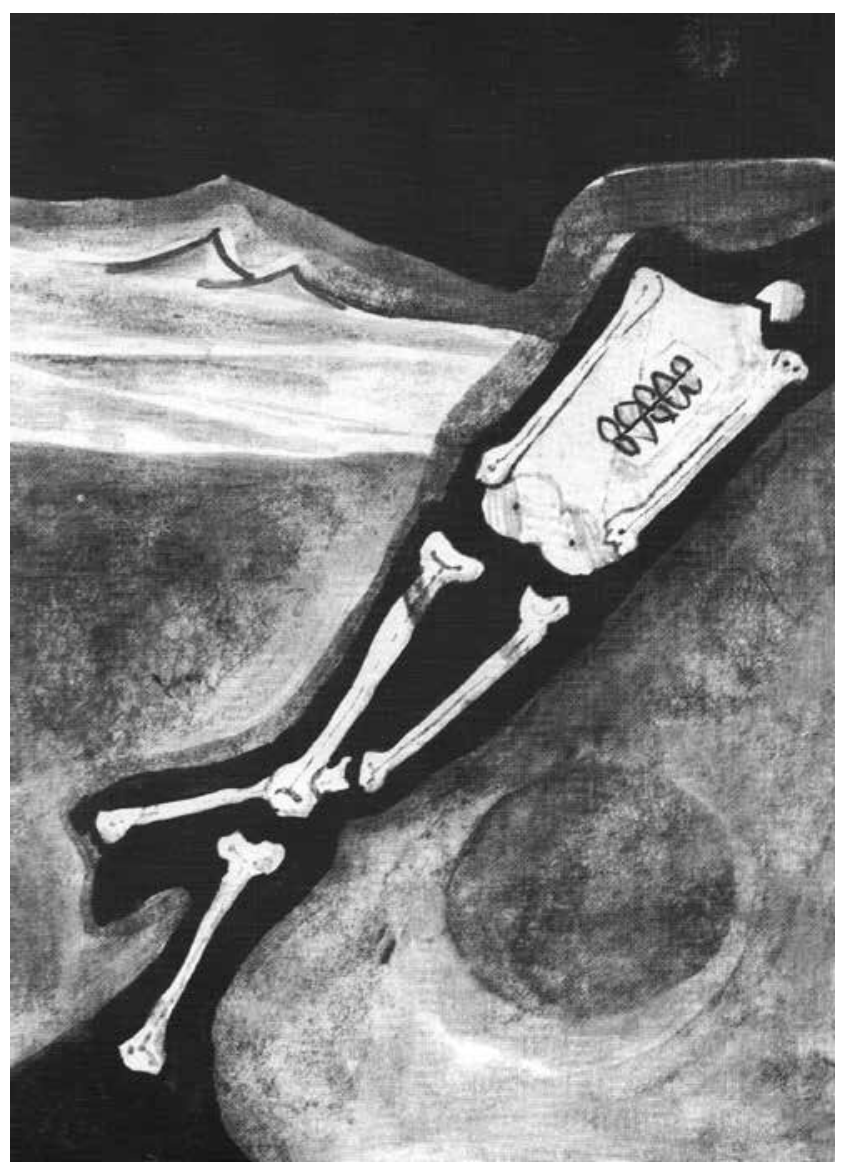

Arribo hoy, transfigurado, a la verdad que implacablemente derrumba

mis viejos pensamientos, mis estíos.

Y no sé si es una brisa levantisca o el devenir incontenible del tiempo de la dicha que me impulsa a decir tierra mía, unidad, venceremos.

Autor: Orlando Sobalvarro, ilustración al poema de Leonel Rugama

(La hoguera que ilumina este rito no es más que el temple

y la razón

de aquellos que cayeron y aún permanecen en pie, cantando los designios de la historia).

Y en un instante la palabra se desborda como un río de luz y balacera.

He allí nuestra heredad: engendramiento o

exterminio,

teoría y praxis, realidad y/o deseo. 


\section{Literatura}

\section{Retrato}

Poseo la gracia de tenderme sobre la hierba y auscultar las gramíneas, los pequeños insectos que saltan del yeso de mis manos al prodigioso corazón de un arcoíris.

También guardo memoria de impasibles devastaciones y uno que otro naufragio personal, ya borroso en mis cuadernos. Levanto los ojos al cielo dormido y percibo el vuelo de algunos nubarrones que oscurecen la mirada limpia de los míos. No lejos del trabajo manual, comparto la canción que anuncia un anhelo universal, un orden nuevo. Sé que la vida baja como un ancho río, y recuerdo a Machado mientras destapo una botella de vino para celebrar las olas de Guiomar, la unidad tantas veces reclamada, las maravillas del amor sediento y este luminoso 26 de Julio en el cual Antonio cumple cien años: casi nada, apenas un poco más que nuestra antigua pena.

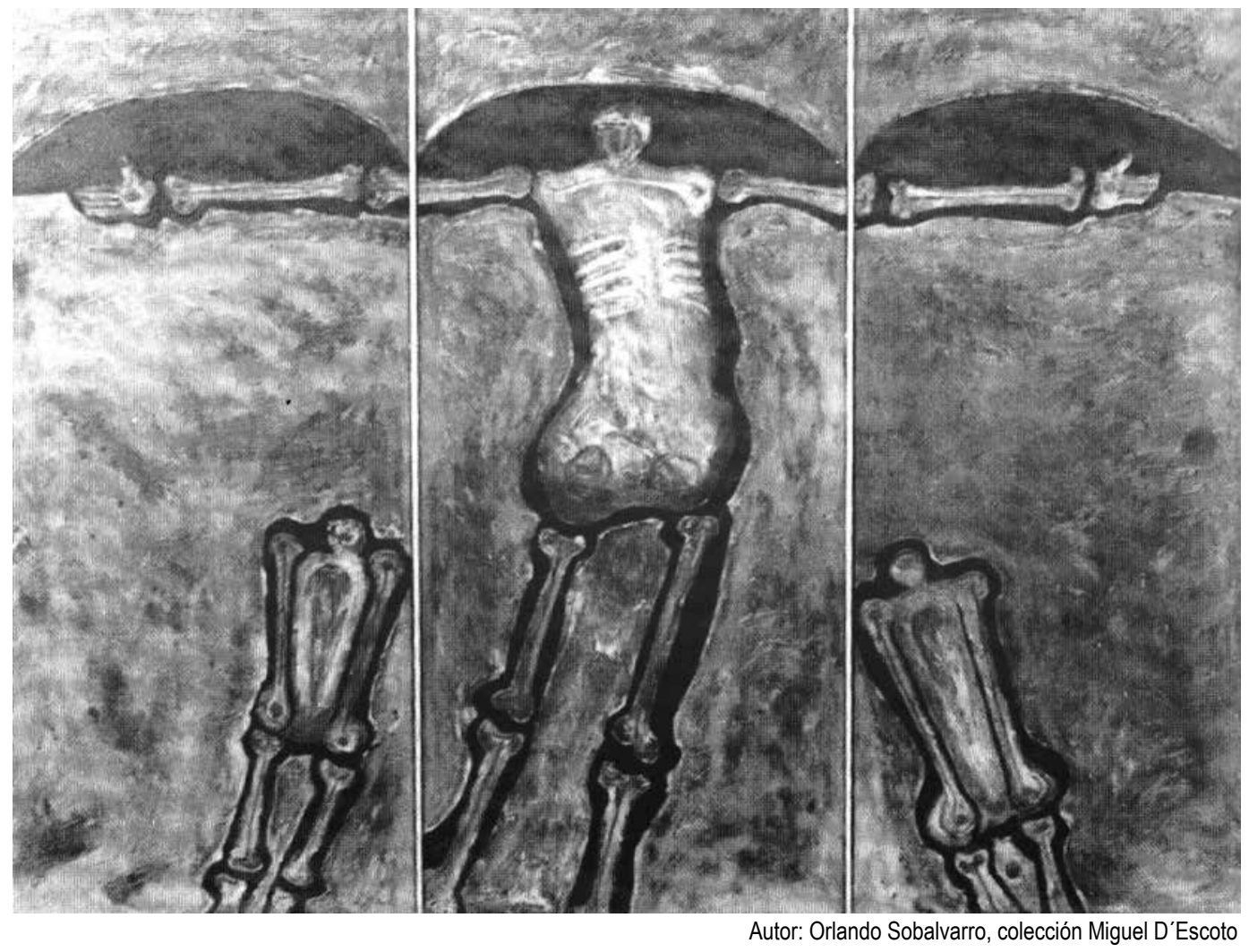




\section{Literatura}

\section{Aura}

Presiento que esta noche, vendrás nuevamente a desovar sobre mi cama un río rubio de relave alcanforado. Es Abril. Dicen que la mar está enferma. Es Abril y ya siento el aura que me llama (quiero decir que me quema), y su voz de aserrín enloquecido resuena subterránea cuando regaña mis penúltimos desmanes. Cortisona más, cortisona menos, las uñas se prenden de la sábana de amianto (aún tiene la huella de tu cuerpo dulce). Y en medio de mi flaqueza expianto los cigarros, las caminatas nocturnas, la vie en rose, los condimentos caseros. Todo se tiñe de amarillo. Poco puka, me digo, poco puka. Todo se tiñe de amarillo. Y debemos cambiar la bisutería gris del paisaje presente. $Y$ yo no puedo levantar ni el meñique. Y lloro en silencio con el pecho cuarteado como una cebolla herida en la penumbra: ¿dónde están mis amigos no los veo, no los veo? Hay mucho amarillo en el pescado. Y cortisona más, cortisona menos, siento que ya la diste sobre la sábana de amianto: un río rubio de relave alcanforado. Y hago un último brindis con los muchachos de la colonia. Y siempre profesor se me viene a la memoria un cuento de Benedetti y algunos versos de J.C (miembros prominentes de nuestra pequeña pero significativa tribu). Pienso en la mujer que amo y en la gatita que soñamos tener y duras penas de chapoteo en las aguas de una cascada inhóspita como mi fría simpatía por la muerte.

Presiento que dormiré algunas horas extras para mañana estar sano y salvo y alegre y juguetón y profesor aún y cambia el paso y arriba Perú (es decir: morir como un alcanfor quemado, una inútil mollera bicolor).

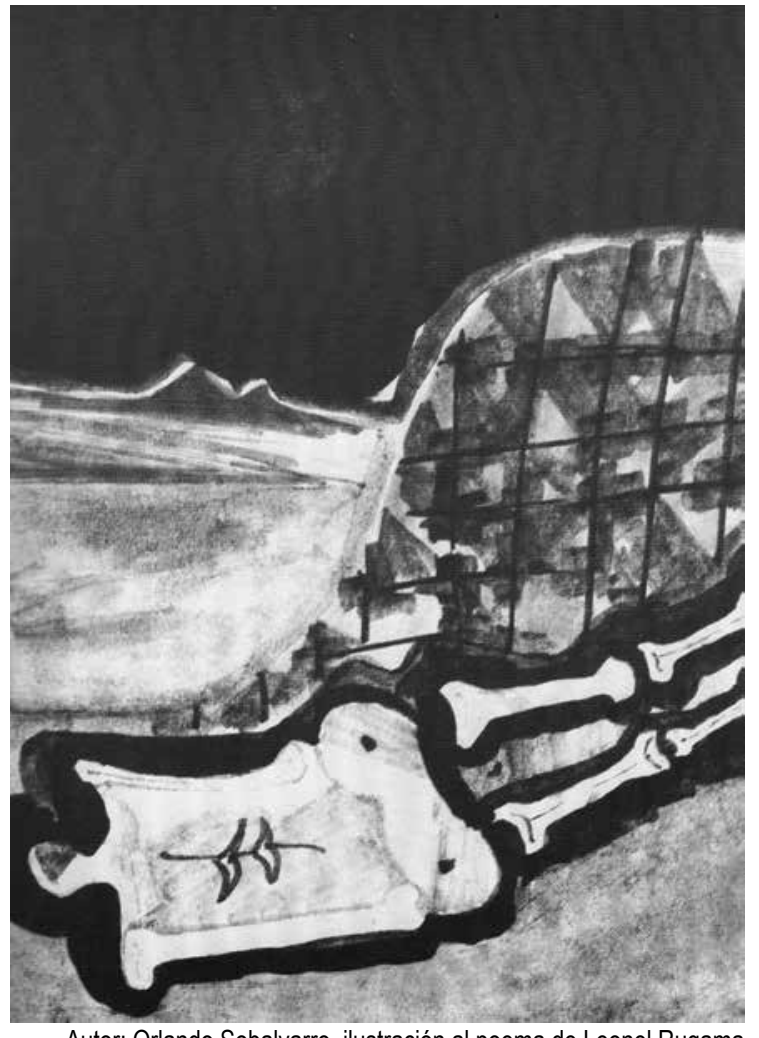

Autor: Orlando Sobalvarro, ilustración al poema de Leonel Rugama 


\section{Literatura}

\section{Benjamin Constant}

Perdidos en el bosque de la ambigüedad desenterramos allá, en Benjamin Constant, la sombra intemporal del desconcierto.

Por la tosca quebrada del verano corría el Amazonas como una muchacha febril, encantada.

Pisoteando

su carne de venado incandescente yo le dije: "insepultos ojos, amigo, insepultos

ojos incendian mi nave que surca por la gamuza triste de tus manos".

Navegamos. Amazonas. Navegamos.

Y junto a la dulce intención de poseer lo que deseamos, no lejos de nosotros, alimentándose de recuerdos inasibles, pequeñas hogueras reverberan.

Navegamos. Amazonas. Navegamos.

Roída por el viento verde de la madrugada, Oh noche que terminas pero que en realidad comienzas: podrás decir ahora, sobre este País donde reina la iniquidad y el contrabando, qué lluvia, qué mujer, qué sol nos depara el destino, oh noche.

Navegamos. Amazonas. Navegamos.

Y en medio de tus aguas que arrastran animales muertos, ilusiones muertas, desconcertando a la razón y a la primavera, bajo la luz agusanada de la luna, el viento y mi guitarra se vierten en lamento.

Navegamos Amazonas. Navegamos. Oh tiempo que arañas indesmayablemente los sueños, los ríos, y todas las criaturas de este mundo ¿dónde la playa más justa, más hermosa que buscamos? Navegamos. Amazonas. Navegamos.

Acosado por el brillo de los oscuros presagios yazgo aquí, innominado, como un viejo soldado de juego, luchando con las duras astas de la aurora que con gozo, con envidia derrumban mi sueño común, absurdo, cotidiano.

Naufragamos.

Amazonas.

Naufragamos.

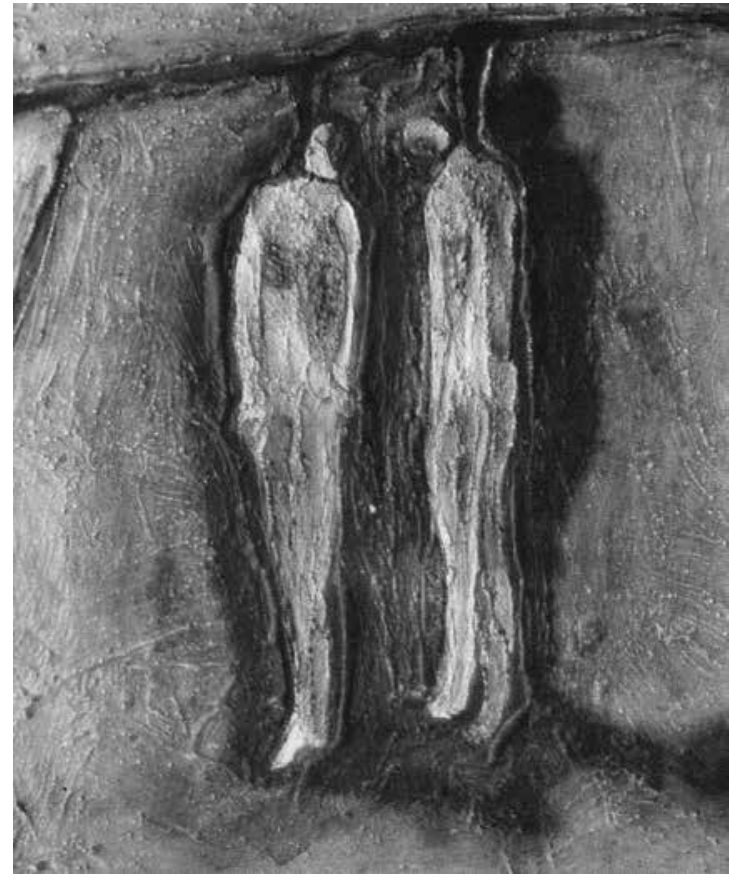

Autor: Orlando Sobalvarro, colección Banco Central de Nicaragua 


\section{Cushillococha}

Lenta

muere la tarde

en el bosque de Cushillococha

Oh juventud, territorio encendido, ¿qué luz, qué voz, qué rostro en la memoria

no guardamos? Aquí, lejos de la desesperación, levantaremos nuestra casa,

y con el tiempo crecerán mis hijos, el horizonte, la vida.

Lenta

muerte la tarde

en el bosque de Cushillococha.

Oh juventud, hontanar de ilusiones, más allá de opacos espejismos - y templados

por la abnegación y el fervor de los sobrevivientes- forjemos un camino

por el cual mañana otros hombres serán lo que no fuimos.

Lenta

muy lenta

muere la tarde en el bosque

de Cushillococha, en tu regazo, amor, en mis manos.

\section{Cantar de Hildebrando}

La luz de todo lo perdido nos envuelve con el leve jazmín

de la nostalgia. Sobre la dura corteza de los años, buscamos

un amor, una palabra

amiga, la huella de los compañeros.

La luz de todo lo perdido nos envuelve con su dulce brebaje

de amargura. Bajo el húmedo polen de los sueños, en el frente del amor hay más reveses que victorias. (No siempre la plenitud es nuestra sombra). La luz de todo lo perdido nos envuelve Con la bruma postrera de estos tiempos. Y marchamos a la intemperie, cara al sol, sorteando halagos, emboscadas, amarillentas ilusiones que oscurecen el camino. La luz de todo lo vivido nos envuelve como ahora y en forma victoriosa la invicta bandera de los pobres.

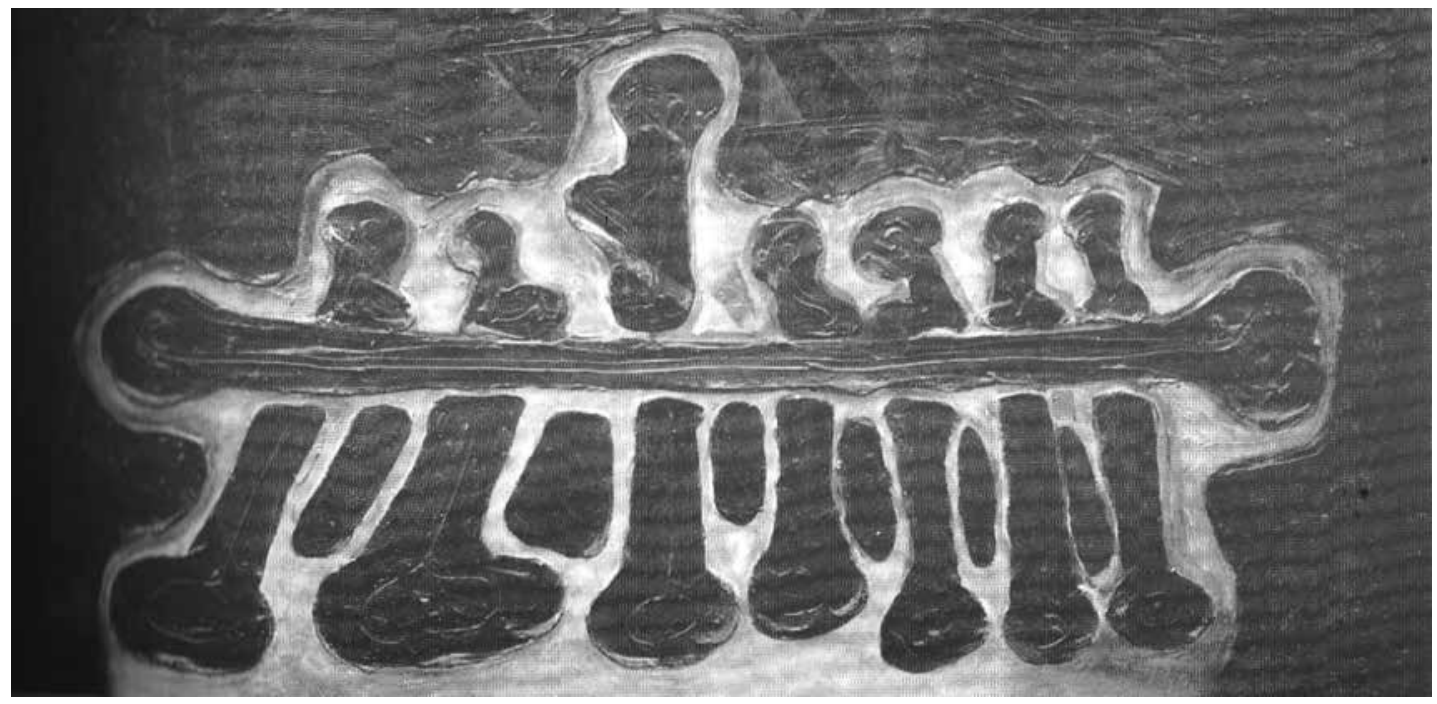

Autor: Orlando Sobalvarro, colección Miguel D’Escoto 